\title{
Reconstruction of the charophyte community of Lake Shinji by oospore collection
}

\author{
T. Komuro ${ }^{1}$, H. Sakayamai ${ }^{2}$, H. Kamiya ${ }^{3}$ and M. Yamamuro ${ }^{1, \star}$ \\ ${ }^{1}$ Graduate School of Frontier Sciences, The University of Tokyo, 5-1-5 Kashiwanoha, 277-8563 Kashiwa, Japan \\ 2 Department of Biology, Graduate School of Science, Kobe University, 1-1 Rokkodai-cho, Nada, 657-8501 Kobe, Japan \\ 3 Shimane Prefectural Institute of Public Health and Environmental Science, 582-1 Nishihamasadacho, 690-0122 Matsue, Japan
}

Received October 30, 2015 - Revised December 16, 2015 - Accepted December 31, 2015

\begin{abstract}
Submerged aquatic vegetation (SAV) aids in maintaining a clear stable state in shallow lakes. However, charophytes are more effective in increasing transparency compared to angiosperms. Lake Shinji was more transparent prior to the beginning of herbicide use for rice weed control in the mid-1950s, because its bottom was covered by SAV up to $3 \mathrm{~m}$ depth. Although Chara braunii C.C. Gmelin and Nitella hyaline (De Candolle) C. Agardh were recorded in the 1960s, there are no reports on SAV in the 1950s. Therefore, in the present study, we aimed to show that the SAV of Lake Shinji was mostly composed of charophytes prior to the 1950s, by conducting a seed analysis. We obtained charophyte oospores from the sediment, but seeds of angiosperms were not identified. In addition to C. braunii that was previously recorded in Lake Shinji, we also found two newly identified species, Chara corallina Willdenow and Chara fibrosa C. Agardh ex Bruzelius. Overall, this study indicates that seed analysis is helpful in reconstructing the former flora of Lake Shinji.
\end{abstract}

Key-words: Seed analysis / water transparency / Chara corallina / submerged aquatic vegetation

\begin{abstract}
Résumé - Reconstruction de la communauté de charophytes du Lac Shinji par collection d'oospores. La végétation aquatique submergée (SAV) aide à maintenir un état clair stable dans les lacs peu profonds. Cependant, les charophytes sont plus efficaces que les angiospermes pour accroître la transparence. Le lac Shinji était plus transparent avant le début de l'utilisation d'herbicides pour le désherbage du riz au milieu des années 1950, parce que son fond était couvert par la SAV jusqu'à $3 \mathrm{~m}$ de profondeur. Bien que Chara braunii C.C. Gmelin et Nitella hyaline (De Candolle) C. Agardh ont été notés dans les années 1960, il n’y a pas de données sur la SAV dans les années 1950. Par conséquent, dans la présente étude, nous avons cherché à montrer que la SAV du Lac Shinji était surtout composée de charophytes avant les années 1950, en procédant à une analyse des semences. Nous avons obtenu des oospores de charophytes du sédiment, mais les graines d'angiospermes n'ont pas été identifiées. En plus de $C$. braunii qui a déjà été enregistré dans le lac Shinji, nous avons aussi trouvé deux espèces nouvellement identifiées, Chara corallina Willdenow et Chara Fibrosa C. Agardh ex Bruzelius. Dans l'ensemble, cette étude indique que l'analyse des semences est utile dans la reconstruction des anciennes flores du lac Shinji.
\end{abstract}

Mots-clés : Analyse de semences / transparence de l'eau / Chara corallina / végétation aquatique submergée

In shallow lakes, submerged aquatic vegetation (SAV) plays a vital role in maintaining a clear stable state (Scheffer et al., 2001). However, previous studies have shown that angiosperms are not as effective in maintaining a clear stable state as charophytes (Van den Berg et al., 1998; Nõges et al., 2005).

Lake Shinji, Japan, is an oligohaline lagoon with a salinity range of $1-10 \mathrm{psu}$ (Figure 1). The lake area is $79.1 \mathrm{~km}^{2}$ and the basin area $1288.4 \mathrm{~km}^{2}$. The maximum depth is $6.4 \mathrm{~m}$, while the average depth is $4.5 \mathrm{~m}$. Hiratsuka et al. (2006) indicated

^ Corresponding author: yamamuro@k.u-tokyo.ac.jp that SAV (unknown species) exists up to 2-3 m depth. Additionally, Komuro and Yamamuro (2013) examined an airborne photograph taken in 1947 by the US Army, and showed that creeping type SAV covered the bottom of Lake Shinji up to $3 \mathrm{~m}$ depth. SAV was previously used as a fertilizer; however, it almost disappeared from Lake Shinji after the beginning of herbicide use for rice weed control in the mid-1950s (Yamamuro, 2012).

Akiyama and Nishigami (1959) collected Chara braunii C.C. Gmelin in 1958, and Kasaki (1964) collected C. braunii and Nitella hyalina (De Candolle) C. Agardh until the late 1960s. Both studies referred to samples that were collected 


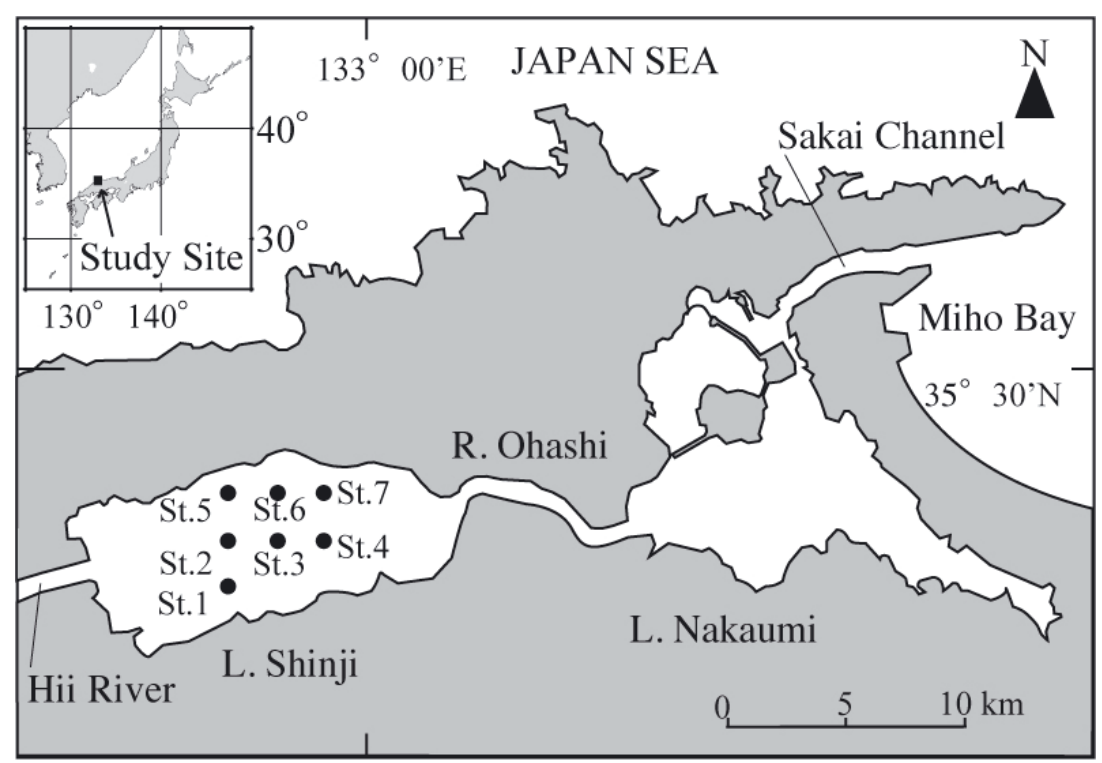

Fig. 1. Location of seven sampling stations (Stations 1-7) in Lake Shinji. Sampling was conducted at Stations 1-7 in 2011, and Stations 2, 4, and 5 in 2013.

from the shoreline of Lake Shinji; thus, it is possible that creeping type SAV at 2-3 m depth comprised other species than those reported in these two studies.

The amount of herbicides used in rice paddies began to decrease after the implementation of a law on the restricted use of herbicides in 2007. As a result, Potamogeton anguillanus Koidz. started to grow in the shallow parts of Lake Shinji (Yamamuro et al., 2014), and its canopy reached the water surface. However, transparency did not increase by the mass coverage of SAV (Yamamuro et al., 2014), which is in disagreement with the alternative stable state theory (Scheffer et al., 2001). A possible explanation could be that Lake Shinji was transparent by the 1960 s, because SAV was mostly composed of charophytes that are considered more effective in increasing transparency (Blindow et al., 2002; Van Donk et al., 2002). The aim of this study was to investigate the composition of past SAV by collecting sediments and conducting seed analysis, in order to show that charophytes, and not P. anguillanus, were dominant when Lake Shinji was transparent before the loss of vegetation due to herbicides.

Sediments were collected from seven stations (Stations 17) of Lake Shinji at depths of more than $5 \mathrm{~m}$, where $99 \%$ of the sediment is composed of silt and mud (Figure 1). The sedimentation rates of these seven stations were reported by Kanai et al. (1997); thus, it was possible to determine the portion of core sediment that accumulated prior to 1960 . The sediment core collection was performed in August 2011 and 2013. In 2011, we sampled all seven stations, and in 2013, we sampled three stations (Stations 2, 4, and 5). A professional diver dived to each station, and gently placed an acrylic tube $(8.5 \mathrm{~cm}$ diameter, $102 \mathrm{~cm}$ length) on the sediment surface in order to prevent any disturbance. The top of the tube was closed with a silicon lid, the tube was pulled out of the sediment surface, and then the bottom of the tube was closed with another silicon lid.

The length of cores was approximately $70 \mathrm{~cm}$. Since the sediment accumulation rate of the sampling station is

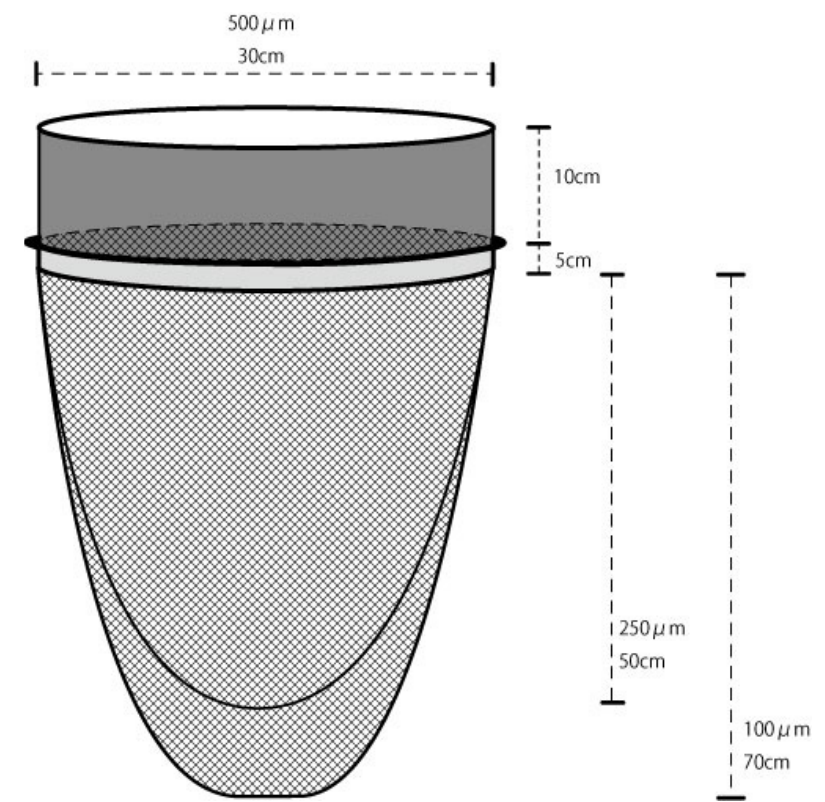

Fig. 2. A representation of the sieve used for sediment sampling in Lake Shinji. Numbers in $\mu \mathrm{m}$ denote the mesh size of the sieve and those in $\mathrm{cm}$ show the diameter of the sieve. The top sieve $(30-\mathrm{cm}$ diameter) is made of stainless steel, while the remaining part is made of plankton net cloth (Komuro and Yamamuro, 2012).

0.04-0.31 $\mathrm{cm} \cdot \mathrm{y}^{-1}$ (Kanai et al., 1997), we removed the top $2-15-\mathrm{cm}$ sediment layer to exclude sediment that accumulated after 1960. We also discarded sediment from a depth of approximately $20 \mathrm{~cm}$ from the bottom layer, because the mud was tightly fixed by diagenesis and precluded sieving. To reduce the amount of sediment required to obtain seeds and oospores by seed analysis, we used a specially designed net sieve as described by Komuro and Yamamuro (2011) (Figure 2). To collect seeds of angiosperms and 
Table 1. Dry weight (DW) of sediments (collected in 2011) on the $250-$ and $100-\mu \mathrm{m}$ mesh sieves.

\begin{tabular}{|c|c|c|}
\hline \multirow{2}{*}{ Station } & \multicolumn{2}{|c|}{ Dry Weight $(\mathrm{g})$} \\
\cline { 2 - 3 } & $250 \mu \mathrm{m}$ & $100 \mu \mathrm{m}$ \\
\hline 1 & 99.4 & 250.3 \\
\hline 2 & 2.6 & 6.4 \\
\hline 3 & 0.8 & 1.9 \\
\hline 4 & 3.5 & 23.8 \\
\hline 5 & 3.8 & 10 \\
\hline 6 & 1.7 & 17 \\
\hline 7 & 2.2 & 13.4 \\
\hline Total & 114.0 & 322.8 \\
\hline
\end{tabular}

charophyte oospores, the sediment was sieved through $100-\mu \mathrm{m}$ and 250- $\mu \mathrm{m}$ mesh sieves (Birks, 2001). The particles that remained on the sieves were transferred to the laboratory and immediately sieved through a $100-\mu \mathrm{m}$ mesh stainless-steel sieve under running water. The particles that remained on the sieve were dried in an oven at $40{ }^{\circ} \mathrm{C}$ until constant weight was reached. The dried particles were sieved again through $100-\mu \mathrm{m}$ and $250-\mu \mathrm{m}$ mesh stainless steel sieves. Since charophyte oospores are usually $200-900 \mu \mathrm{m}$ in length and 200 $500 \mu \mathrm{m}$ in width, we expected that most oospores would be retained on the $250-\mu \mathrm{m}$ mesh sieve. The remaining particles were separately examined using a digital binocular microscope (Keyence, Osaka, Japan) in order to collect seeds and oospores.

Because the length of sediments used for seed analysis in 2011 differed between the sampling stations, the dry weight (DW) of sediments on the $250-\mu \mathrm{m}$ mesh, as well that on the $100-\mu \mathrm{m}$ mesh also differed (Table 1). We did not measure the DW of sediments on the $100-\mu \mathrm{m}$ mesh and $250-\mu \mathrm{m}$ mesh that were used for seed analysis in 2013. We assumed that coarse particles predominated at Station 1, which is near the river mouth, while mud predominated at all other stations; thus, most sediments were lost during sieving.

Charophyte oospores were observed under a scanning electron microscope (SEM) as described by Sakayama et al. (2002) with some modifications. Before observation, oospores were cleaned by incubation in $10 \%$ Triton-X 100 at $60{ }^{\circ} \mathrm{C}$ for more than $12 \mathrm{~h}$, subjected to acetolysis or sonicated for approximately $2 \mathrm{~min}$, and transferred to centrifuge tubes with distilled water. Acetolysis was not performed in species that had fragile flanges on the surface of oospores. Then, oospores were dehydrated in an ethanol series $(50 \%$ and $70 \%)$, mounted on brass or aluminum stubs with double-side adhesive tape, airdried, sputter-coated with gold, and viewed under S-2150N and S-4800 scanning electron microscopes (Hitachi, Tokyo, Japan) at 10-20 kV. Oospore identification was performed as described by Kasaki (1964), Wood (1965), Imahori and Kasaki (1977), Casanova (2013), and Casanova and Karol (2014) and maintained at the University of Tokyo, Kashiwa, Japan.

Angiosperm seeds were not obtained in any of the sediments; however, charophyte oospores were identified in sediments sampled in both 2011 and 2013. The total number of

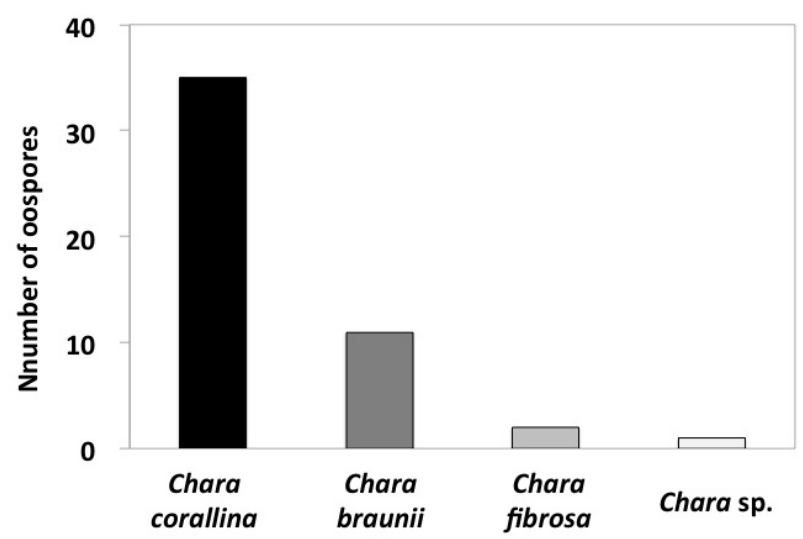

Fig. 3. Number of Chara corallina, Chara braunii, Chara. fibrosa, and Chara sp. oospores collected from Lake Shinji in 2011 and 2013.

oospores obtained in two years was 49 (Figure 3). Detailed information on the number of oospores at each station in 2011 and 2013 is presented in Table 2. Using SEM, we identified four different charophyte species, C. braunii, Chara corallina Willdenow, Chara fibrosa C. Agardh ex Bruzelius, and Chara sp. (Figure 4). We obtained 35 oospores of C. corallina, 11 of C. braunii, two of C. fibrosa, and one of Chara sp. (Table 2). Overall, $C$. corallina was the most abundant species, in terms of oospore number and the number of stations obtained from. To the best of our knowledge, this is the first record of C. corallina and C. fibrosa in Lake Shinji.

The number of oospores per DW of sediment $(>100-\mu \mathrm{m})$ varied from 0.05 to 1.09 among sampling stations (0.05 oospores $\cdot \mathrm{g}^{-1}$ of DW sediment, 0.22 oospores $\cdot \mathrm{g}^{-1}$ of DW sediment, 0.37 oospores $\cdot \mathrm{g}^{-1}$ of DW sediment, 0.92 oospores $\cdot \mathrm{g}^{-1}$ of DW sediment, 1.09 oospores $\cdot \mathrm{g}^{-1}$ of DW sediment, 0.64 oospores. ${ }^{-1}$ of DW sediment, and 0.64 oospores. $\mathrm{g}^{-1}$ of DW sediment at Stations $1,2,3,4,5$, 6 , and 7 , respectively). These densities were much lower than those in previous studies on recent fossil oospores (i.e., Davidson et al., 2005; Rodrigo et al., 2010). For example, the number of oospores and gyrogonites in the sediments of Albufera de Valéncia lagoon (area $23 \mathrm{~km}^{2}$, mean depth 1-2 m) was more than 30 (Rodrigo et al., 2010). In Lake Shinji, creeping type SAV, possibly charophytes, covered the bottom up to $3 \mathrm{~m}$ depth (Komuro and Yamamuro, 2013). Since Lake Shinji is bigger than other studied lakes (i.e., Groby Pool, area $0.12 \mathrm{~km}^{2}$; Davidson et al., 2005), sediments at up to $3 \mathrm{~m}$, composed of sand and organic materials, are removed by strong wave actions and transported to deeper lake basin depths, which may explain the fact that we collected sediment samples from depths exceeding $5 \mathrm{~m}$. In such case, the density of oospores is diluted during transportation and sedimentation.

Before the 1950s, when herbicides were not used in rice paddies, the transparency of Lake Shinji was assumed to be $4 \mathrm{~m}$ (Komuro and Yamamuro, 2013) and, based on an airborne photograph, SAV was of creeping type. After 2007 that the use of herbicides decreased, $P$. anguillanus covered the shallows of Lake Shinji; however, transparency remained stable at approximately $1 \mathrm{~m}$ (Yamamuro et al., 2014). Our results showed that the sediments of Lake Shinji before 1960 included only 
T. Komuro et al.: Knowl. Manag. Aquat. Ecosyst. (2016) 417, 12

Table 2. Number of Chara corallina, Chara braunii, Chara fibrosa, and Chara sp. oospores collected from Lake Shinji (Stations 1-7) in 2011 and 2013.

\begin{tabular}{|c|c|c|c|c|c|c|c|c|}
\hline \multirow{2}{*}{ Station } & \multicolumn{2}{|c|}{ Chara corallina } & \multicolumn{2}{c|}{ Chara braunii } & \multicolumn{2}{c|}{ Chara fibrosa } & \multicolumn{2}{|c|}{ Chara sp. } \\
\cline { 2 - 9 } & 2011 & 2013 & 2011 & 2013 & 2011 & 2013 & 2011 & 2013 \\
\hline 1 & 1 & & 2 & - & 0 & - & 0 & - \\
\hline 2 & 0 & 0 & 0 & 4 & 2 & 0 & 0 & 0 \\
\hline 3 & 1 & - & 0 & - & 0 & - & 0 & - \\
\hline 4 & 19 & 1 & 0 & 2 & 0 & 0 & 1 & 0 \\
\hline 5 & 4 & 1 & 1 & 0 & 0 & 0 & 0 & 0 \\
\hline 6 & 2 & - & 0 & - & 0 & - & 0 & - \\
\hline 7 & 6 & - & 2 & - & 0 & - & 0 & - \\
\hline Total & 33 & 2 & 5 & 6 & 2 & 0 & 1 & 0 \\
\hline
\end{tabular}

-: denotes that no sediment sampling was conducted

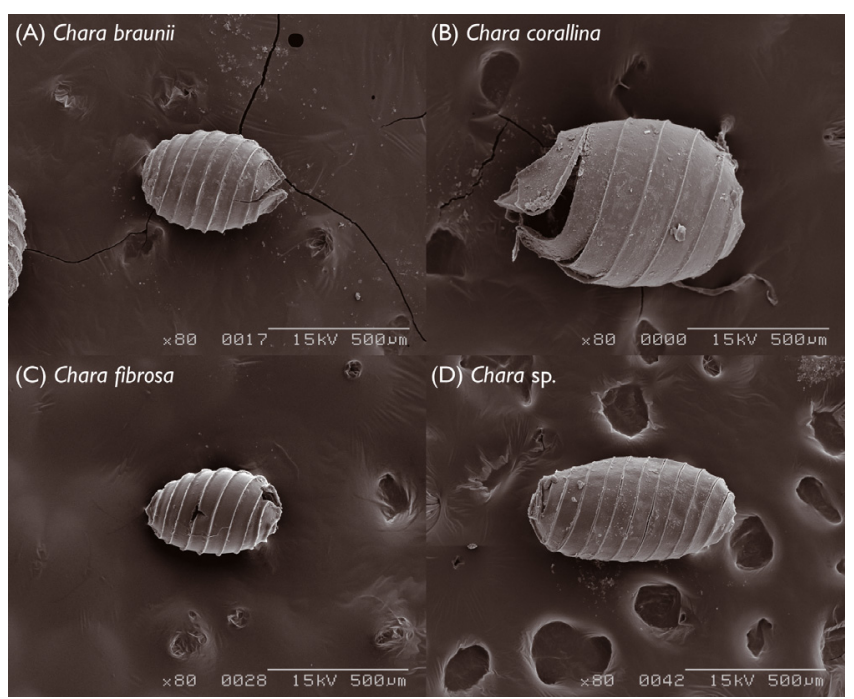

Fig. 4. Scanning electron micrograph of (A) Chara braunii, (B) Chara corallina, (C) Chara fibrosa, and (D) Chara sp.

charophytes, which is in accordance with our previous study (Komuro and Yamamuro, 2013).

The present study suggested that charophytes play an important role in maintaining the water transparency in the lake, and thus, invasive angiosperms did not play any role in terms of improving transparency. We found that $C$. corallina was the most abundant charophyte before the reduction in SAV due to herbicide use. Among calcified charophytes, C. corallina contains relatively high calcium content (Kawahata et al., 2013). Calcium can induce the clear water state by absorbing the phosphate in the water column (Hilt et al., 2006).

This study indicates that seed analysis is helpful in reconstructing the former flora, which has not been recorded in the literature. The flora before the use of herbicides differed from that which appeared after the reduction in herbicide use, probably because of the invasion of exotic species in the lake. Overall, these results show that the flora appearing after the decrease in human disturbance does not always revive the original flora. Thus, our study contributes important information that can be useful in conservation and management programs of aquatic ecosystems.

Acknowledgements. We would like to thank Mr. Yukitaka Koyama and Mr. Yuki Nakamura for their help during collecting sediments. We would also like to thank Ms. Yui Nakajima for her help during the preparation for field work, and Ms. Misato Shimizu and Ms. Aoi Shibata for their kind assistance with SEM observations. This work was supported by the Grants-in-Aid for Scientific Research (KAKENHI) (Nos. 24310053 and 24570100) and the River Works Technology Research and Development Program of the Japanese Ministry of Land, Infrastructure, Transport, and Tourism.

\section{References}

Akiyama M. and Nishigami K., 1959. Ecological studies on algal flora in Lake Shinji and Nakano-umi: PartT: Distribution of macroscopic algae. Bull. Shimane Univ., 9, 9-75.

Birks H.H., 2001. Plant Macrofossils. In: Smol J.P., Birks H.J.B. and Last W.M. (eds.), Tracking Environmental Change Using Lake Sediments. 3, Kluwer Academic Publishers, 49-74.

Blindow I., Hargeby A. and Andersson G., 2002. Seasonal changes of mechanisms maintaining clear water in shallow lake with abundant Chara vegetation. Aquat. Bot., 72, 315-334.

Casanova M.T., 2013. Review of the species concepts Chara fibrosa and C. flaccida (Characeae, Charophyceae). Aust. Syst. Bot., 26, 291-297.

Casanova M.T. and Karol K.G., 2014. A revision of Chara sect. Protochara, comb. et stat. nov. (Characeae: Charophyceae). Aust. Syst. Bot., 27, 23-37.

Crawford S.A., 1979. Farm pond restoration using Chara vulgaris vegetation. Hydrobiologia, 62, 17-32.

Davidson T.A., Sayer C.D., Bennion H., David C., Rose N. and Wade M.P., 2005. A 250 year comparison of historical, macrofossil and pollen records of aquatic plants in a shallow lake. Freshwater Biol., 50, 1671-1686.

Hilt S., Gross E.M., Hupfer M., Morscheid H., Mahlmann L., Melzer A., Poltz J., Sandrock S., Scharf E.M., Schneider S. and Weyer K.V., 2006. Restoration of submerged vegetation in shallow eutrophic lakes-A guideline and state of the art in Germany. Limnologia, 36, 155-171. 
Hiratsuka J., Yamamuro M. and Ishitobi Y., 2006. Satoumi Moku tori monogatari. (The story of harvesting submerged aquatic plant), Seibutsu Kennkyu-Sha, Tokyo, 141 p.

Imahori K. and Kasaki H., 1977. Class Charophyceae. In: Hirose, H. and Yamagishi, T. (eds.) Uchida Rokakuho Publishing, Tokyo, 761-829.

Jeppesen E., Sondergaard M., Sondergaard M. and Christoffersen K., 1998. The structuring role of submerged macrophytes in lakes, Springer, New York, 423 p.

Kanai Y., Inouchi Y., Yamamuro M. and Tokuoka T., 1997. Sedimentation rate and environment in Lake Shinji, Shimane prefecture. J. Jpn Geochem., 32, 71-85.

Kasaki H., 1964. The Charophyta from the lakes of Japan. J. Hattori Bot. Lab., 27, 217-314.

Kawahata C., Yamamuro M. and Shirakawa Y., 2013. Changes in alkaline band formation and calcification of corticated charophyte Chara globuraris. SpringerPlus, 2, 85.

Komuro T. and Yamamuro M., 2012. Development of a shipboard apparatus for use in sieving lacustrine sediments containing oospores and seeds of aquatic vegetation. Jpn J. Bull. Water Plant Soc., 97, 29-33.

Komuro T. and Ymamuro M., 2013. Estimation of the aquatic plant community area in Lake Shinji reconstructed with the aerial photographs taken by the US forces in 1940's. Jpn J. Ecol. Civil Eng., $16,51-59$.

Nõges P., Tuvikene L., Feldmann T., Tõnnno I., Künnap H., Luup H., Salujõe J. and Nõges T., 2003. The role of charophytes in increasing water transparency: a case study of two shallow lakes in Estonia. Hydrobiologia, 506, 567-573.
Rodrigo M.A., Alonso-Guillén J.L. and Soulié-Märsche I., 2010. Reconstruction of the former charophyte community out of the fructifications identified in Albufera de València lagoon sediments. Aquat. Bot., 92, 14-22.

Sakayama H., Nozaki H., Kasaki H. and Hara Y., 2002. Taxonomic re-examination of Nitella (Charales, Charophyceae) from Japan, based on microscopical studies of oospore wall ornamentation and rbcL gene sequences. Phycologia, 41, 397-408.

Scheffer M., Carpenter S., Foley J.A., Folke C. and Walker B., 2001. Catastrophic shifts in ecosystems. Nature, 413, 591-596.

Van den Berg M.S., Scheffer M. and Coops H., 1998. The role of Characeaen algae in the management of eutrophic shallow lakes. J. Phycol., 34, 750-756.

Van Donk E. and van de Bund W.J., 2002. Impact of submerged macrophytes including charophytes on phyto- and zooplankton communities: allelopathy versus other mechanisms. Aquat. Bot., 72, 261-274.

Wood R.D., 1965. Monograph of the Characeae. In: Wood, R.D. and Imahori, K. (eds.) J. Cramer, Weinheim, 1-904.

Yamamuro M., 2012. Herbicide-induced macrophyte-tophytoplankton shifts in Japanese lagoons during the last 50 years: consequences for ecosystem services and fisheries. Hydrobiologia, 699, 5-19.

Yamamuro M., Kamiya H. and Ishitobi Y., 2014. Water quality before and after the break out of submerged plants at Lake Shinji. Jpn J. Limnol., 75, 99-105.

Yoshimura S., 1937. Kosyougaku (Limnology), Sanseidou, Tokyo, $427 \mathrm{p}$.

Cite this article as: T. Komuro, H. Sakayamai, H. Kamiya, M. Yamamuro, 2016. Reconstruction of the charophyte community of Lake Shinji by oospore collection. Knowl. Manag. Aquat. Ecosyst., 417, 12. 